\title{
Assessment of Environmental External Effects in Power Generation
}

Meyer, Henrik Jacob; Morthorst, Poul Erik; Ibsen, Liselotte Schleisner; Meyer, Niels I; Nielsen, Per Sieverts; Nielsen, Vilhjalmur

\section{Publication date:}

1996

Document Version

Publisher's PDF, also known as Version of record

Link back to DTU Orbit

Citation (APA):

Meyer, H. J., Morthorst, P. E., Ibsen, L. S., Meyer, N. I., Nielsen, P. S., \& Nielsen, V. (1996). Assessment of Environmental External Effects in Power Generation. Denmark. Forskningscenter Risoe. Risoe-R No. 938(EN)

\section{General rights}

Copyright and moral rights for the publications made accessible in the public portal are retained by the authors and/or other copyright owners and it is a condition of accessing publications that users recognise and abide by the legal requirements associated with these rights.

- Users may download and print one copy of any publication from the public portal for the purpose of private study or research.

- You may not further distribute the material or use it for any profit-making activity or commercial gain

- You may freely distribute the URL identifying the publication in the public portal

If you believe that this document breaches copyright please contact us providing details, and we will remove access to the work immediately and investigate your claim 
RISO-R- $-938(E N)$

Risø-R-938(EN)

\section{Assessment of Environmental External Effects in Power Generation}

Henrik Meyer, Poul Erik Morthorst, Lotte Schleisner Niels I. Meyer*, Per Sieverts Nielsen*, Vilhjálmur Nielsen*

*The Technical University of Denmark, Lyngby

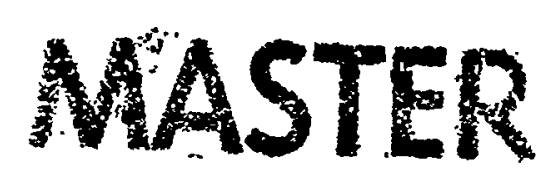

DISTRAPUTION OF JH'S DOCUMENT BS EWLMITED

$R B$

Risø National Laboratory, Roskilde

December 1996 


\section{Abstract}

This report summarises some of the results achieved in a project carried out in Denmark in 1994 concerning externalities. The main objective was to identify, quantify and - if possible - monetise the external effects in the production of energy, especially in relation to renewable energy technologies.

The report compares environmental externalities in the production of energy using renewable and non-renewable energy sources, respectively. The comparison is demonstrated on two specific case studies. The first case is the production of electricity based on wind power plants compared to the production of electricity based on a coalfired conventional plant. In the second case heat/power generation by means of a combined heat and power plant based on biomass-generated gas is compared to that of a combined heat and power plant fuelled by natural gas.

In the report the individual externalities from the different ways of producing energy are identified, the stress caused by the effect is assessed, and finally the monetary value of the damage is estimated. The method is applied to the local as well as the regional and global externalities.

The report is an extract of the Danish report "Omkostningsopgørelse for miljøeksternaliteter i forbindelse med energiproduktion" financed by the Danish Energy Agency (j.nr. 51191/92-0067). In connection with the project a seminar report in English also has been published: "Seminar on External Effects in the Utilisation of Renewable Energy" (Risø National Laboratory \& Technical University of Denmark, September 1993).

ISBN 87 -550-2239-1

ISSN 0106-2840

Grafisk Service, Riso, 1996 
Contents

4.1 WIND ENERGY

4.2 CONVENTIONAL COAL-FIRED CONDENSING PLANT

13

4.3 CHP PLANT FUELLED BY BIOMASS

15

4.4 CHP PLANT FUELLED BY NATURAL GAS 
Risø-R-938(EN) 


\section{DISCLAIMIER}

Portions of this document may be illegible in electronic image products. Images are produced from the best available original document. 


\section{Introduction}

This report summarises some of the results achieved in a project carried out in Denmark in 1994 concerning externalities. The main objective was to identify, quantify and - if possible - monetise the external effects in the production of energy, especially in relation to renewable energy technologies.

The project has been carried out in a collaboration between the Technical University of Denmark and Risø National Laboratory. The following persons have participated in the project:

Henrik Meyer,

Poul Erik Morthorst,

Lotte Schleisner,

Niels I. Meyer,

Per Sieverts Nielsen,

Vilhjalmur Nielsen,
Risø National Laboratory

Risø National Laboratory

Risø National Laboratory

The Technical University of Denmark

The Technical University of Denmark

The Technical University of Denmark

The prices mentioned in the report are in ecu. The rate of exchange used is 1 ecu $=7.5$ Dkr. 


\section{Project delimitation}

Two case studies have been considered in this project:

- A wind energy case, where wind turbines substitute a coal-fired condensing plant

- A biomass case, where a combined heat and power plant fuelled by biomass substitutes a small-scale natural gas-fired combined heat and power plant (CHP-plant)

The externalities are thus assessed for four technologies: wind power, coal-fired condensing plant, biomass CHP-plant and a natural gas CHP-plant. All are defined as new highly developed technologies, ready to be introduced into the energy system. The use of the technologies is assumed to be marginal to the system and not cause any changes in the existing price relations.

In relation to the assessment of externalities, only the environmental costs are considered. Thus, social and economic costs, e.g. those related to changes in employment or depletion of resources, are not included in the project. The cost concept is based on marginal damage cost, in principle taking as starting point the level of pollution that exists today. A discount rate of $1.5 \%$ p.a. in real terms is used, reflecting the time preference rate.

The external effects are assessed and split into three geographical areas:

- Local, which is damage occurring within a vicinity of $50 \mathrm{~km}$ from the plant

- Regional, relating to any damage occurring within a radius of $3000 \mathrm{~km}$ from the plant

- Global, damage attributed to greenhouse gases.

As mentioned above, the assessment of the marginal damage costs takes as it starting point the level of pollution that exists today. This is possible when it concerns the local and regional effects, because most types of damage are identifiable today, but when the assessment relates to global effects, these are not identifiable today. Thus, the treatment of damage caused by greenhouse gases gives rise to a number of methodological problems, requiring specific assumptions in the analysis.

Externalities in relation to greenhouse gas-produced damage are analysed using an IPCC-scenario for the development of $\mathrm{CO}_{2}$-emissions. According to IPCC, a doubling of the $\mathrm{CO}_{2}$-concentration in the atmosphere will lead to an increase in the global average temperature of approx. $2.5^{\circ} \mathrm{C}$. A scenario is chosen where the doubling of $\mathrm{CO}_{2}$ in the atmosphere is expected to take place within a 50 year time span, which means that by 2045 the mean global temperature will be $2.5^{\circ} \mathrm{C}$ higher than today. Damage caused by this temperature increase is assessed in year 2045, mainly based on international literature. To estimate an average damage cost over this fifty-year period a linear relationship between the level of $\mathrm{CO}_{2}$ concentration in the atmosphere and the damage level is assumed. 
Thus, from a methodological viewpoint the local/regional and global external effects are treated quite differently, and adding the costs of these various effects to yield a total should be done with caution. Finally, it should be pointed out that the uncertainties related to the assessment of externalities are very high, especially regarding damage caused by greenhouse gas emissions. 


\section{Methodology}

To ensure that all relevant externalities are taken into account a methodology involving a number of steps were developed. Figure 1 shows the five steps that were included.

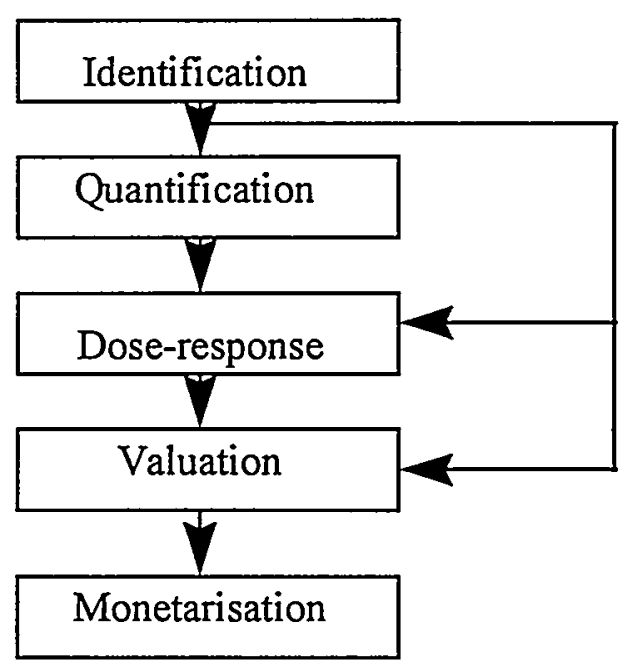

Figure 1. Methodology for assessing externalities

The identification involves a description of all the processes in the energy production of the specific technology. The processes include the total fuel and construction cycle of the technology (cf. Figure 2). For a coal-fired power plant the fuel-cycle consists of the mining of coal, its transportation storage, and electricity production, and finally, the treatment of residuals. The plant is constructed, operated for a number of years, and finally scrapped. Influences on the environment in these stages of the fuel-cycle and the life-cycle of the plant are identified, although with regard to the construction and scrapping of the plant only the related emissions from energy use are considered. 


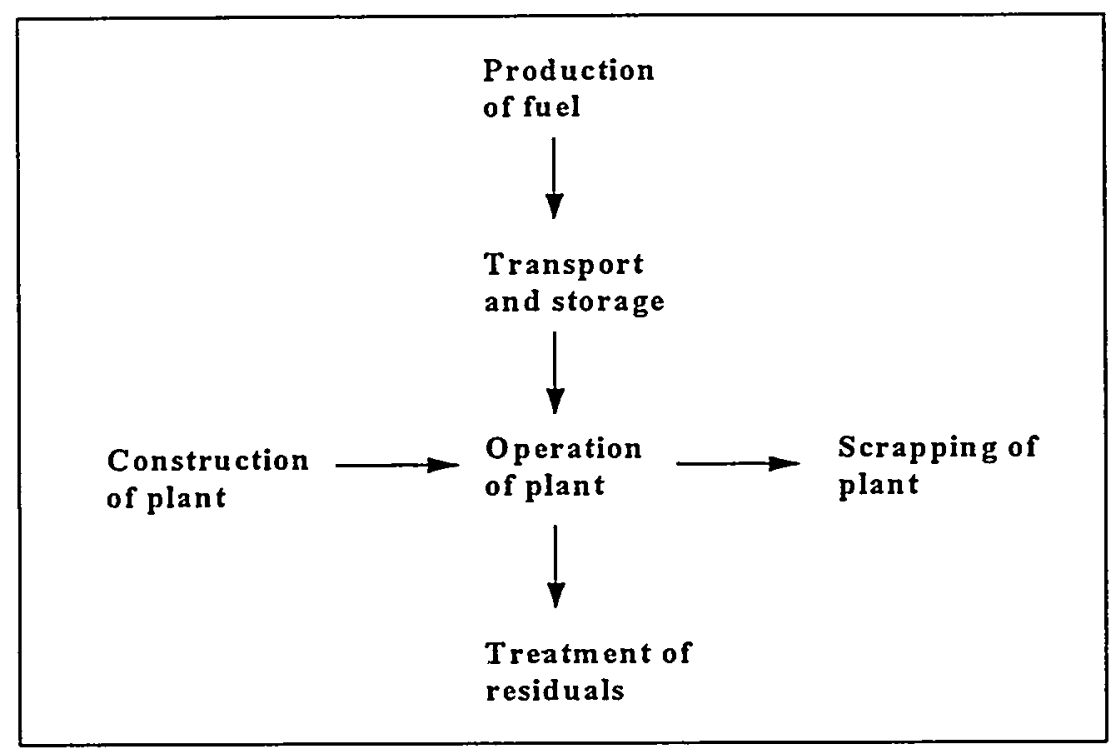

Figure 2. Processes in the assessment of externalities

The identification is a preliminary structural analysis, where the environmental influences from the energy production, and the damage caused by these influences are specified. The environmental influences are classified in the following groups:

1. Emissions to air

2. Emissions to water

3. Emissions to soil

4. Sound disturbance

5. Electromagnetic radiation

6. Influence on flora and fauna

7. Influence on natural surroundings

8. Influence on traffic

The quantification step is a quantification of those influences that were estimated to be important in the identification, for instance $\mathrm{CO}_{2}$-emission by combustion from a coalfired power plant.

Following this, the effects on the environment of the quantified influences are assessed in dose-response functions. An example of this is how the emission of $\mathrm{SO}_{2}$ results in acid rain, and how the damage from the acid rain can be quantified in terms of lost timber.

In the valuation step the aim is to estimate the monetary value of the damage. For example, the price of lost timber or of fresh water .

Finally, the monetised value of the external effect might be calculated by multiplying the results from the last-mentioned steps:

Monetising of the externality $=$ quantity $*$ dose-response ${ }^{*}$ price 
Quantity is the quantified influence given from the quantification step, dose-response is the damage that the quantified influence results in per unit, and the price is the price per unit of damage. An example of the monetising is shown in Table 1.

Table 1. Example of monetising externalities

\begin{tabular}{|llll|}
\hline Monetised externality & Influence & Dose-response & Value \\
\hline $\begin{array}{l}\text { Costs of loss in fresh water } \\
(\$ / G W h)\end{array}$ & $\mathrm{CO}_{2}$ & $*$ Loss in fresh water & * Price of fresh water \\
$($ ton $/ \mathrm{GWh})$ & $\left(\mathrm{m}^{3} /\right.$ ton $\left.\mathrm{CO}_{2}\right)$ & $\left(\$ / \mathrm{m}^{3}\right)$ \\
\hline
\end{tabular}




\section{Assessment of externalities}

A serious problem in the assessment of the extent of the externalities is the uncertainty related to the assessment. The uncertainty is due to different conditions, the main ones being:

1. Insufficient knowledge of the dose-response effect.

2. The time horizon.

3. Irreversibility.

It is possible to reduce the first condition by more research in this area, but it is impossible to reduce the uncertainty related to assessing externalities in a time horizon of 50 years. This means that all the externalities are subject to uncertainty, and the externalities will therefore be estimated in an interval.

\subsection{Wind energy}

In the case of wind energy a $500-\mathrm{kW}$ wind turbine and a small wind farm of $5 \mathrm{MW}$, i.e. 10 wind turbines, have been assessed. In order to be able to compare wind power with a coal-fired plant a gas turbine is introduced together with the wind turbine as a back-up technology for the wind turbine in periods without wind. The energy system wind turbine/gas turbine will in this way be able to produce electricity at any time and is therefore comparable to the coal-fired plant in this respect.

As the gas turbine is established as a back-up technology to the wind turbine system, it will only be in operation in smaller periods. Therefore only externalities related to the construction of the gas turbine will be considered in the following.

The processes that have been assessed in the identification process of the energy system wind turbine/gas turbine are the following:

- Construction and establishment of the wind turbine

- Presence of the wind turbine

- Operation and maintenance of the wind turbine

- Scrapping of the wind turbine

- Construction of the gas turbine

For each process an identification of the environmental influences and a quantification of the most important influences have been carried out.

The only influences identified in the construction and establishment of the wind turbine are emissions to the air due to the energy used in the mining of the materials and fabricating of the components of the wind turbine. The most important emissions in this process are $\mathrm{CO}_{2}, \mathrm{SO}_{2}$ and $\mathrm{NO}_{x}$.

The presence of the wind turbine will influence the nature both in a visual and recreational way. Visually the wind turbine will influence the horizon. This may have 
either a positive or negative effect depending on the viewer. The experience of a walk in the nature may be disturbed by the presence of the wind turbine. This is the recreational effect.

The influences identified for operating and maintaining wind turbines are as follows:

- Sound disturbance

- Electromagnetic radiation

- Influence on flora and fauna

- Emissions to air

Sound disturbance is an atmospheric influence caused by the operation of the wind turbine.

The rotation of the blades gives rise to disturbing light reflections as well as electromagnetic radiation at radio and television frequencies, which can disturb reception in nearby residences.

Influence on flora and fauna is a mechanical influence due to the rotation of the blades. This may influence the life of birds nearby the wind turbine, also there may be problems if a blade is destroyed, hitting people on ground.

Emissions to the air are connected to the operation and maintenance of the wind turbine, where the production of various new components will cause emissions.

Scrapping of the wind turbine will result in some emissions to the air, especially from the burning of fibre glass.

The construction and operation of the gas turbine used as backup will also give rise to emissions to the air due to the production of various materials to the gas turbine.

Of the above-mentioned influences only the following wind-energy related environmental damages have been found relevant and important to quantify:

- Sound disturbance

- Emissions to air

The quantified influences and damages are shown in Table 2.

Table 2. Quantified influences and damage for wind energy

\begin{tabular}{|l|c|c|}
\hline Influences & $\begin{array}{l}\text { Quantification } \\
500 \mathrm{~kW} \text { wind turbine }\end{array}$ & $\begin{array}{l}\text { Quantification } \\
5 \mathrm{MW} \text { wind farm }\end{array}$ \\
\hline Emissions to air $(\mathrm{g} / \mathrm{kWh})$ & & $11-27$ \\
$\mathrm{CO}_{2}$ & $11-27$ & $0.04-0.1$ \\
$\mathrm{NO}_{\mathrm{x}}$ & $0.04-0.1$ & $0.05-0.13$ \\
$\mathrm{SO}_{2}$ & $0.05-0.13$ & \\
\hline Sound disturbance & & $0.05-0.2 * 10^{-6}$ \\
(residences $/ \mathrm{kWh})$ & $0.1-0.4^{*} 10^{-6}$ & \\
\hline
\end{tabular}




\subsection{Conventional coal-fired condensing plant}

The assessment of the environmental externalities in connection with energy production based on coal is related to a conventional coal-fired condensing plant with a rated capacity of $350 \mathrm{MW}$. The plant is a marginal one equipped with a desulphurisation unit able to remove $85 \%$ of the $\mathrm{SO}_{2}$-emission and de- $\mathrm{NO}_{\mathrm{x}}$ burners reducing the $\mathrm{NO}_{\mathrm{x}}$-emission about $70 \%$.

The following processes are assessed:

- Construction of the plant

- Fuel cycle

- Presence and operation of the plant

- Scrapping of the plant

The fuel cycle consists of various processes as shown in Figure 3. As seen from the figure there is no national transportation of coal in Denmark. The reason for this is that the coal is transported by ship directly to storage in the harbour in the area of the coalfired plant.

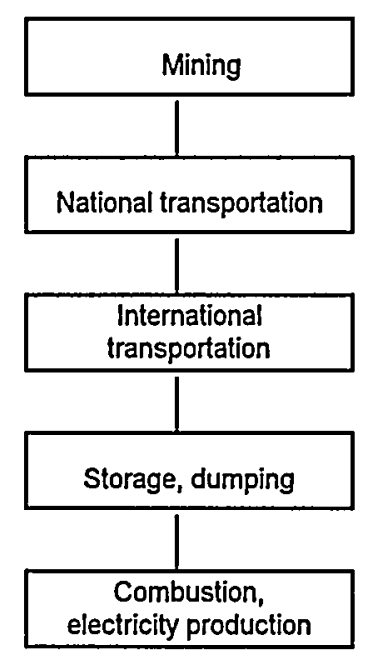

Figure 3. The fuel cycle

Each of the four processes: Construction of the plant, fuel cycle, presence and operation of the plant and scrapping of the plant has been assessed in regard to environmental influences and damage. The influences identified for all the processes are as follows:

- Emissions to the air

- Emissions to the ground

- Emissions to the sea

- Sound disturbance

- Influence on flora and fauna

- Influence on natural surroundings

- Influence on traffic 
Emissions to the air will occur in all the processes due to production of materials, coal emissions from the mining, transportation of coal by ship, storage of coal and electricity production.

Emissions to the ground are caused by the storage of fly ash during the electricity production process.

Emissions to the sea occur from oil leakage during transportation of the coal by ship.

Sound disturbances are present in many processes. During the mining there will be machinery noise, during transportation there will be noise from railways and by coal loading, and in the electricity production process itself and the operation of the power plant there will be sound disturbances.

The influence on flora and fauna is caused by the presence of the mine; during the electricity production process there will be an influence on flora and fauna due to the desulphurisation process, where large amounts of chalk will be excavated. Also the presence of the plant will be a disturbing influence on the nature in the area.

Influence on nature experience is also caused by the presence of the mine and by the presence of the plant.

The transportation of coal by railway and by vehicles from the mines will affect the normal flow of traffic, but also transportation to and from the plant by personal during operation will affect the traffic.

Of the above-mentioned influences the following most important ones have been quantified:

- Emissions to the air

- Sound disturbance

- Influence on flora and fauna

The quantified influences and damage are shown in Table 3 . Some of the emissions will take place at sea. These emissions at sea will not cause any damage in connection with acid rain. 
Table 3. Quantified influences and damage for coal

\begin{tabular}{|l|c|}
\hline \multicolumn{1}{|c|}{ Influences } & $\begin{array}{c}\text { Quantification } \\
\text { 350 MW coal plant }\end{array}$ \\
\hline Emissions to air $(\mathrm{g} / \mathrm{kWh})$ at land & \\
$\mathrm{CO}_{2}$ equivalents & $875-1018$ \\
$\mathrm{NO}_{\times}$ & $1.03-1.21$ \\
$\mathrm{SO}_{2}$ & $1.15-1.32$ \\
$\mathrm{Particles}$ & $0.17-0.19$ \\
VOC & $0.02-0.03$ \\
$\mathrm{NMVOC}$ & $0.04-0.06$ \\
\hline Emissions to air $(\mathrm{g} / \mathrm{kWh})$ at sea & \\
$\mathrm{NO}_{x}$ & $0.47-0.79$ \\
$\mathrm{SO}_{2}$ & $0.35-0.58$ \\
\hline Sound disturbance/ Influence on flora and fauna & \\
(residences $/ \mathrm{kWh})$ & $1.9-7.4^{*} 10^{-9}$ \\
\hline
\end{tabular}

\subsection{CHP plant fuelled by biomass}

The combined heat and power plant fuelled by biomass, which has been assessed in relation to environmental externalities, is a decentral CHP plant fuelled by wood chip gas. The plant consists of a fluid-bed gasification plant followed by gas and steam turbines. The plant has a capacity of $40 \mathrm{MW}$. In the assessment of externalities the heat efficiency is assumed to be $200 \%$, while the electricity efficiency is $40 \%$.

The processes that are assessed are the following:

- Construction of the plant

- Fuel cycle

- Presence and operation of the plant

- Scrapping of the plant

The fuel cycle consists of the processes shown in Figure 4. 


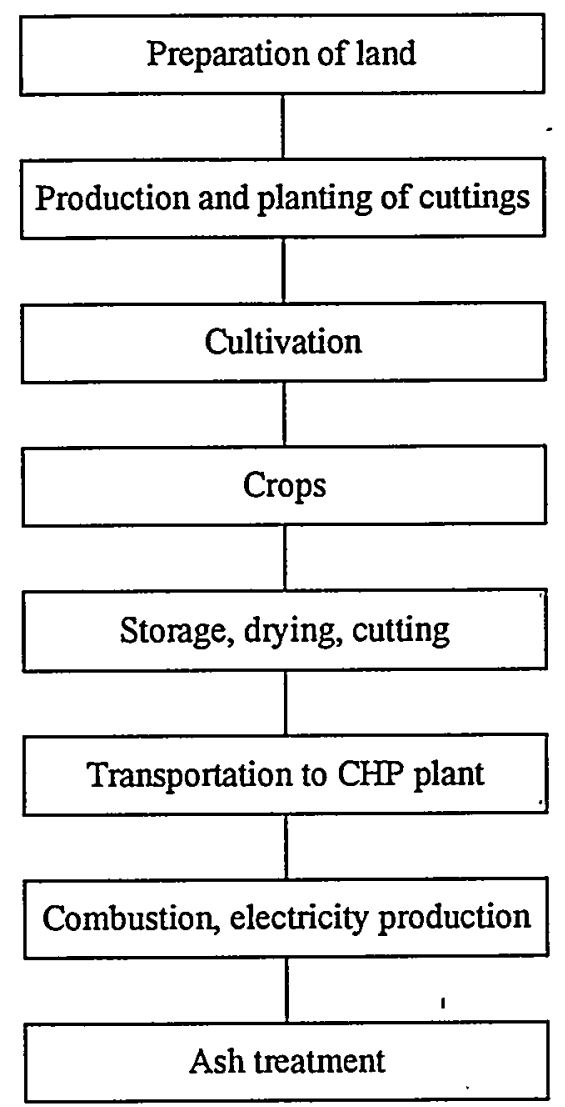

Figure 4. Fuel cycle for biomass

Each of the processes has been assessed in regard to environmental impacts. The following impacts have been identified:

- Emissions to air

- Emissions to soil

- Emissions to ground water

- Sound disturbance

- Influence on flora and fauna

- Influence on natural surroundings

- Influence on traffic

- Wear and tear on roads

Emissions to air will occur in all processes due to the production of materials, cultivation of energy forest and cutting of wood chips. The transportation of wood chips to the plant and emissions to the air will also occur during the energy production. Emissions to air is therefore quite an important impact from the biomass cycle.

Emissions to ground is an impact caused by the cultivation of the energy forest, as the fertiliser contains nitrate, which will be emitted to the ground. Also the use of herbicides 
will cause emissions to the ground. This kind of impact is especially attached to the cultivation of biomass.

Emissions to ground water is like the emissions to ground, an impact caused by the cultivation of the energy forest, and thereby especially attached to biomass.

Sound disturbance will take place especially during the fuel cycle process. The use of tractors and harvest machines will cause noise, and the cutting of wood chips will cause a lot of noise. Finally, the transportation of wood chips by trucks to the CHP plant will be a noise disturbance.

The influence on flora and fauna is a result of cultivation of the energy forest, as the cultivation will change the flora and fauna in the cultivated area.

The influence on natural surroundings is one caused by an increase of humus in the ground due to the cultivation. This increase will make the willow grow very fast to a height of 4-6 meter. The growth will be very crowded and solid blocking the view.

Finally, the traffic and the roads will be influenced by the heavy transportation of wood chips to the CHP plant by trucks.

The above-mentioned impacts have been assessed, but only the most important have been quantified and monetised. These impacts are as follows:

- Emissions to air

- Emissions to ground

- Influence on traffic

- Wear and tear on roads

The quantified influences and damage are shown in Table 4.

Table 4. Quantified influences and damage for biomass

\begin{tabular}{|l|c|}
\hline \multicolumn{1}{|c|}{ Influences } & $\begin{array}{c}\text { Quantification } \\
40 \mathrm{MW} \text { biomass CHP plant }\end{array}$ \\
\hline Emissions to air $(\mathrm{g} / \mathrm{kWh})$ & \\
$\mathrm{CO}_{2}$ equivalents & $63-150$ \\
$\mathrm{NO}_{x}$ & $1.4-2.1$ \\
$\mathrm{SO}_{2}$ & $0.095-0.19$ \\
$\mathrm{Particles}$ & $0.031-0.063$ \\
$\mathrm{NMVOC}$ & $1.6-16$ \\
$\mathrm{NH}_{3}$ & $0.12-0.14$ \\
\hline Emissions to ground & $0-0.002$ \\
(m ${ }^{3}$ groundwater/kWh) & \\
\hline Influences on traffic / wear and tear & $1.1-3.2$ \\
(m/kWh) & \\
\hline
\end{tabular}




\subsection{CHP plant fuelled by natural gas}

The plant that is analysed in order to assess influences and externalities is a decentral combined heat and power plant fuelled by natural gas. The plant has a capacity of 45.6 MW. In the assessment of externalities the heat efficiency is assumed to be $200 \%$, while the rest of the natural gas consumption will be used for electricity production. Hereby the production efficiency of the electricity will be $55.6 \%$.

The processes that are assessed are the same as for the biomass plant:

- Construction of the plant

- Fuel cycle of natural gas

- Presence and operation of the plant

- Scrapping of the plant

The fuel cycle of natural gas consists of various processes as shown in Figure 5.

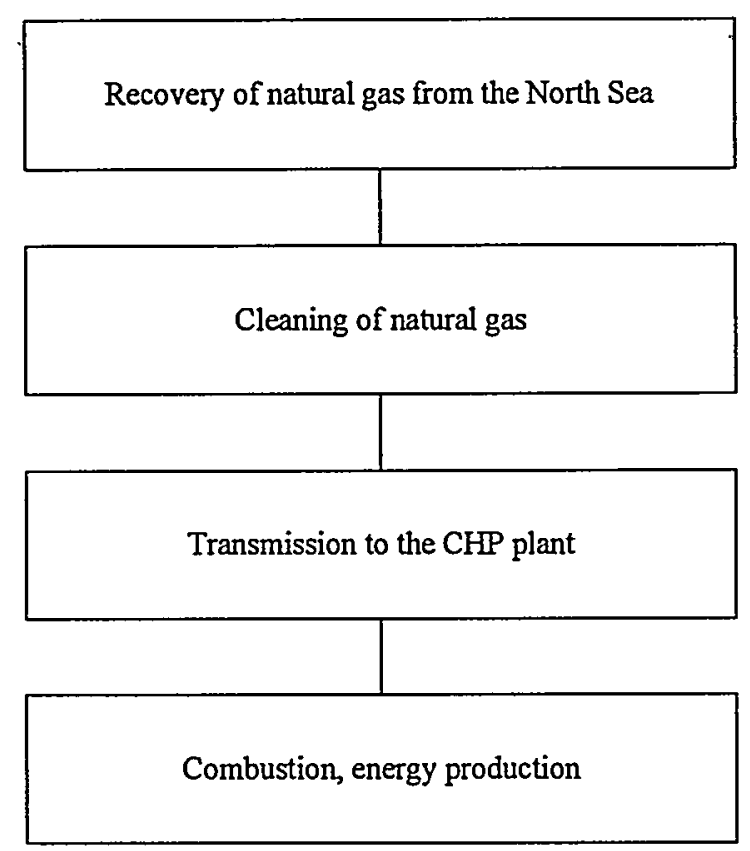

Figure 5. Fuel cycle for natural gas

For the processes: Construction of the plant, fuel cycle of natural gas, presence and operation of the plant and scrapping of the plant, the following impacts have been identified:

- Emissions to air

- Emissions to sea

- Sound disturbance

- Influence on traffic

Emissions to air is the most important impact in the natural gas cycle. The emissions to air will take place during the construction of the plant due to material production, and during the recovery of natural gas, as there will be an emission of natural gas to the 
atmosphere in this phase. Also the energy use for production of platforms will cause emissions to the air. Finally, emissions to the air are a result of the energy production based on natural gas.

Emissions to sea are a result of the recovery phase, where leaks of oil may occur from the platforms. These leaks will cause pollution of the sea.

Sound disturbance will be present during the energy production as a result of the operation of pumps, turbines etc., but the noise will be noticeable only very close to the plant.

During the construction of the pipeline for natural gas local traffic will be influenced due to the work of digging ditches for the pipes. However, this effect will be only of limited duration.

Of the above-mentioned impacts the emissions to air is the most important from the natural gas cycle. The quantification of the emissions is shown in Table 5. As shown in the table some of the emissions will be those at sea, but will have no effect on acidification.

Table 5. Quantified influences from natural gas

\begin{tabular}{|l|c|}
\hline \multicolumn{1}{|c|}{ Influences } & $\begin{array}{c}\text { Quantification } \\
\text { MW natural gas } \mathrm{CHP} \\
\text { plant }\end{array}$ \\
\hline Emissions to air $(\mathrm{g} / \mathrm{kWh})$ on land & $382-415$ \\
$\mathrm{CO}_{2}$ equivalents & $0.83-0.9$ \\
$\mathrm{NO}_{x}$ & $0.012-0.034$ \\
$\mathrm{SO}_{2}$ & $(3.8-4.2)^{*} 10^{-5}$ \\
$\mathrm{Particles}^{-5}$ & $0.054-0.079$ \\
$\mathrm{NMVOC}$ & \\
\hline Emissions to air $(\mathrm{g} / \mathrm{kWh})$ at sea & $0.086-0.092$ \\
$\mathrm{NO}_{\mathrm{x}}$ & $\sim 0$ \\
$\mathrm{SO}_{2}$ & $(1.7-1.9) * 10^{-6}$ \\
$\mathrm{Particles}$ & \\
\hline
\end{tabular}




\section{Monetising local and regional externalities}

The quantified local and regional influences are summarised in Table 6.

Emissions to air from wind power are based only on the energy expended in the initial construction of the plant. For wind power the influence of noise/visual impact on nearby residents is especially important. Coal-fired plants have the highest impact regarding gaseous emissions, especially $\mathrm{SO}_{2}$. Approx. $35 \%$ of $\mathrm{SO}_{2}$ and approx. $55 \%$ of $\mathrm{NO}_{\mathrm{x}}$ emissions from coal arise from sources abroad. The amount of emissions to ground in connection to the biomass plant is so small, that it will be neglected in the monetarisation phase.

Table 6. Quantified local and regional influences

\begin{tabular}{|c|c|c|c|c|}
\hline Influences & Wind power & $\begin{array}{l}\text { Coal-fired } \\
\text { plant }\end{array}$ & $\begin{array}{l}\text { Biomass } \\
\text { plant }\end{array}$ & $\begin{array}{l}\text { Natural } \\
\text { gas plant }\end{array}$ \\
\hline Local & \multirow{7}{*}{$0.1-0.4 * 10^{-6}$} & \multirow{7}{*}{$1.9-7.4 * 10^{-9}$} & & \multirow{7}{*}{$\sim 0$} \\
\hline Emissions to air, particles ( $\mathrm{g} / \mathrm{kWh}$ ) & & & $0.03-0.06$ & \\
\hline Emissions to ground & & & & \\
\hline$\left(\mathrm{m}^{3}\right.$ groundwater $\left./ \mathrm{kWh}\right)$ & & & $0-0.002$ & \\
\hline Influences on residences $/ \mathrm{kWh}$ & & & & \\
\hline Increased transportation $(\mathrm{m} / \mathrm{kWh})$ & & & $1.1-3.2$ & \\
\hline Increased wear and tear $(\mathrm{m} / \mathrm{kWh})$ & & & $1.1-3.2$ & \\
\hline \multirow{2}{*}{\multicolumn{5}{|c|}{$\begin{array}{l}\text { Regional } \\
\text { Emissions to air ( } \mathrm{g} / \mathrm{kWh})\end{array}$}} \\
\hline & & & & \\
\hline$-\mathrm{SO}_{2}$ & $0.05-0.13$ & $1.15-1.32$ & $0.1-0.2$ & $0.01-0.03$ \\
\hline$-\mathrm{NO}_{\mathrm{x}}$ & $0.04-0.1-$ & $1.03-1.21$ & $1.4-2.1$ & $0.83-0.9$ \\
\hline - NMVOC & & $0.04-0.06$ & $1.6-16$ & $0.05-0.08$ \\
\hline
\end{tabular}

The dose-response functions for the local/regional externalities are shown in Table 7.

Table 7. Dose-response for local and regional externalities

\begin{tabular}{|c|c|c|}
\hline Consequences & Influence & Dose-response \\
\hline $\begin{array}{l}\text { Local } \\
\text { Health effects } \\
\text { - Illness } \\
\text { Death }\end{array}$ & $\begin{array}{l}\text { Particles } \\
\text { Particles }\end{array}$ & $\begin{array}{l}\text { 1.9-6.7 days/ton } \\
0.7-1.8 * 10^{-4} \mathrm{dead} / \text { ton }\end{array}$ \\
\hline $\begin{array}{l}\text { Regional } \\
\text { Loss in forestry } \\
\text { Loss in agriculture } \\
\text { Health damage } \\
\text { - Stay in hospital } \\
\text { - Loss of working days }\end{array}$ & $\begin{array}{l}\mathrm{SO}_{2}, \mathrm{NO}_{x} \\
\mathrm{SO}_{2} \\
\text { Particles } \\
\text { Particles }\end{array}$ & $\begin{array}{l}0.4-1.6 \text { ton biomass/ton } \\
0.15-0.6 \text { ton biomass/ton } \\
0.05-0.2 \text { stays/ton } \\
11.3-40.0 \text { days/ton }\end{array}$ \\
\hline
\end{tabular}


In general, a considerable variation is found in the dose-response estimates, mainly due to inhomogeneties in the categories. Most of the dose-response estimates are based on studies carried out for the European Commission (ref.1). The dose-response functions have been adjusted Danish conditions with regard to the amount of biomass, yield, population, etc. Monetary valuations of the damage are listed in Table 8 for the local and regional areas. The estimates are based on Danish market prices.

Table 8. Costs of local and regional consequences

\begin{tabular}{|l|l|}
\hline \multicolumn{1}{|c|}{ Consequences } & \multicolumn{1}{c|}{ Price } \\
\hline Health effects & $99-149 \mathrm{ecu} /$ day \\
- Illness (loss of working days) & $343-568 \mathrm{ecu} /$ day \\
- Stays in hospital & $0.44-0.7 \mathrm{mill} . \mathrm{ecu} / \mathrm{life}$ \\
Loss in fresh water & $0.2-0.5 \mathrm{ecu} / \mathrm{m}^{3}$ \\
Loss in agriculture & $145-185 \mathrm{ecu} / \mathrm{ton}$ yield \\
Loss in forestry & $53-85 \mathrm{ecu} / \mathrm{ton}$ tree \\
Damage to buildings / monuments & $185-1320 \mathrm{ecu} / \mathrm{ton} \mathrm{SO}_{2}$ \\
Visual, recreational, noise damage & $30-90 \mathrm{ecu} / \mathrm{kWh} / \mathrm{year}$ \\
Unsafe traffic & $0.05-0.07 \mathrm{ecu} / \mathrm{km}$ \\
Wear and tear on roads & $0.02-0.03 \mathrm{ecu} / \mathrm{km}$ \\
\hline
\end{tabular}

The valuation of human life is based on the loss of salary. The yearly salary in Denmark has been set to 235.000 ecu on average and the length of a working life is estimated to 40 years. The rate of discount is set to $1.5 \%$. Death caused by the emission of particles is on average assumed to happen after 17.5-22.5 years of working life, and the valuation of human life is therefore estimated to the loss of salary for the years remaining, corresponding to a loss of $0.44-0.7$ mill. ecu/life.

Figure 6 shows the monetised local and regional externalities. 


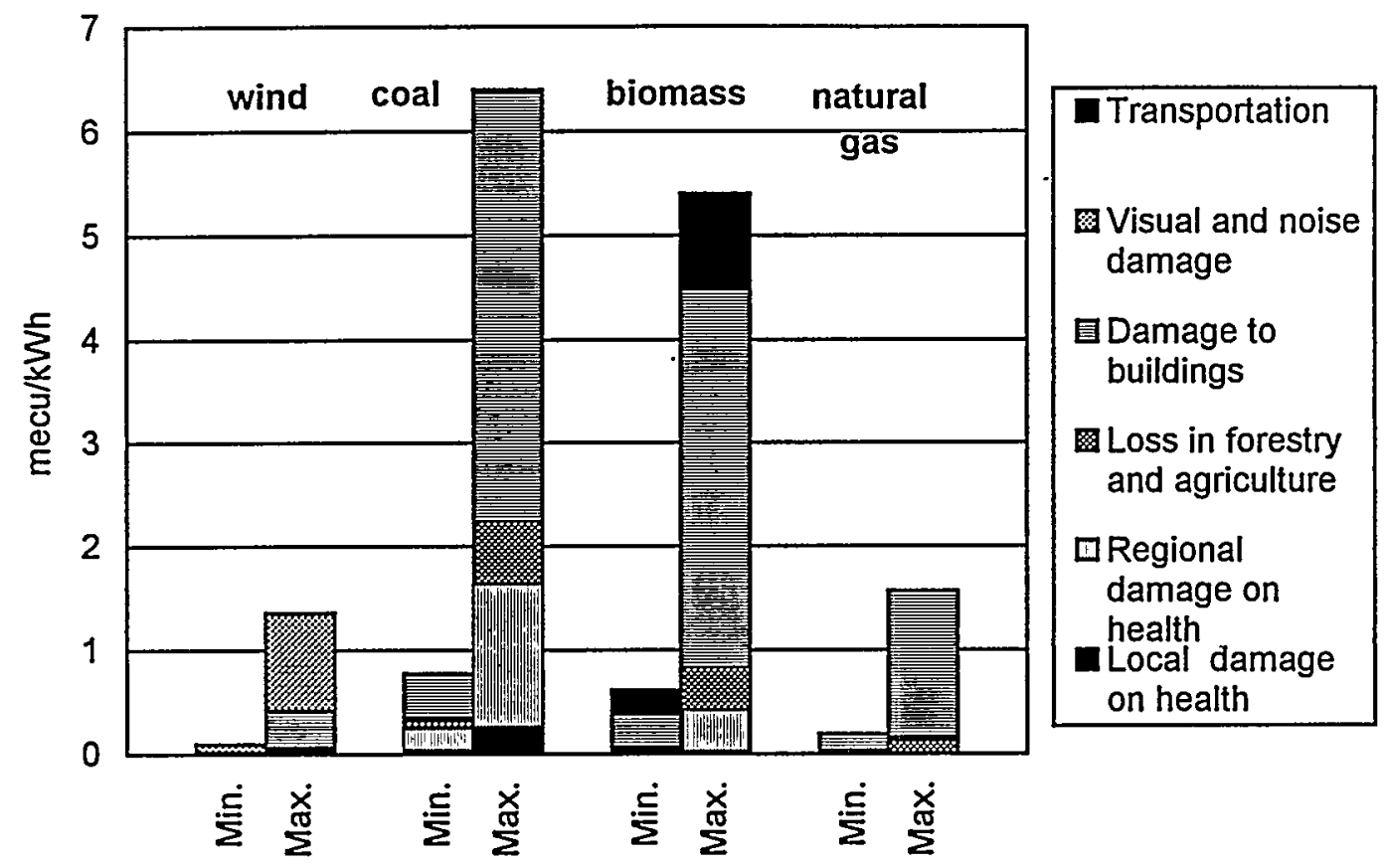

Figure 6. Monetised local and regional externalities

Concerning local externalities, the most important are influences on residences (noise and visual impact) and increased transportation, and these are significant only for wind power and biomass, respectively. For regional externalities only damage to buildings (including monuments) really matters, and this is especially important for coal-fired and biomass plants.

In general, the estimated local and regional externalities are found to be moderate. The main reason for this is that the analysis is performed for new highly developed technologies. Using existing average plants in the analysis would have increased the level of emissions substantially. 


\section{Monetising global externalities}

The global emissions that have been quantified in the project are $\mathrm{CO}_{2}, \mathrm{CH}_{4}, \mathrm{CO}$ and $\mathrm{N}_{2} \mathrm{O}$. These emissions have been converted to $\mathrm{CO}_{2}$ equivalents by means of global warming potential factors (GWP). The quantified and calculated $\mathrm{CO}_{2}$-equivalents for the four technologies are given in Table 9.

Table 9. Quantified global influences

\begin{tabular}{|l|c|c|c|c|}
\hline & Wind power & Coal-fired plant & Biomass plant & Natural gas plant \\
\hline $\begin{array}{l}\mathrm{CO}_{2} \text {-equivalents } \\
(\mathrm{g} / \mathrm{kWh})\end{array}$ & $11-27$ & $875-1018$ & $63-150$ & $382-415$ \\
\hline
\end{tabular}

The emission of greenhouse gases is considerable for the coal-fired power plant, while the emission of these gases and particulates in the wind power case is limited to what takes place in the construction of the plant. Dose-responses for global emissions are shown in Table 10. As mentioned, the dose-responses are evaluated for year 2045, given a doubling of the concentration of $\mathrm{CO}_{2}$ in the atmosphere by that year.

Table 10. Dose-response for global emissions

\begin{tabular}{|l|c|}
\hline \multicolumn{1}{|c|}{ Consequences } & $\begin{array}{c}\text { Year 2045 } \\
\text { (damage/Gton } \mathrm{CO}_{2} \text { ) }\end{array}$ \\
\hline Increased mortality, dead & $5,500-22,000$ \\
Loss in fresh water, $\mathrm{m}^{3}$ & $0.3-2.7 * 10^{10}$ \\
Loss in agriculture, ton yield & $0.9-3.8 * 10^{6}$ \\
Loss in sealand, $\mathrm{km}^{2}$ & $80-230$ \\
Loss in mainland, $\mathrm{km}^{2}$ & $40-120$ \\
\hline
\end{tabular}

The costs of the damage caused by greenhouse emissions are evaluated for 2045 as well (cf. Table 11). The global dose-response functions are based on various international studies (ref.2, ref.3, ref.4). Concerning death related to global warming the valuation of human life is based on the loss of salary as for the local and regional externalities, but for the global externalities the difference in salary in various parts of the world are considered.

Some of the consequences, listed in Table 11, are not evaluated using dose-response functions, but monetised directly in relation to the influence (emission). 
Table 11. Costs of global consequences year 2045

\begin{tabular}{|l|l|}
\hline \multicolumn{1}{|c|}{ Consequences } & \multicolumn{1}{c|}{$\begin{array}{c}\text { Price, year } 2045 \\
(1993 \text { prices })\end{array}$} \\
\hline Increased mortality & $0.13-0.54$ mill. ecu/life \\
Loss in agriculture & $105-264$ ecu/ton yield \\
Loss in forestry & $0.07-0.11 * 10^{3}$ mill. ecu/Gton $\mathrm{CO}_{2}$ \\
Loss in biodiversity & $0.13-1.06 * 10^{3}$ mill. ecu/Gton $\mathrm{CO}_{2}$ \\
Coast protection & $0.01-0.15 * 10^{3} \mathrm{mill}$. ecu $/ \mathrm{Gton} \mathrm{CO}_{2}$ \\
Loss in sealand & $1.06-3.04 \mathrm{mill}$. ecu $/ \mathrm{km}^{2}$ \\
Loss in mainland & $1.06-3.04 \mathrm{mill}$. ecu $/ \mathrm{km}^{2}$ \\
Room heating / cooling & $0.15-0.63 * 10^{3} \mathrm{mill}$. ecu/Gton $\mathrm{CO}_{2}$ \\
Tourism & $0-0.3 * 10^{3} \mathrm{mill}$. ecu/Gton $\mathrm{CO}_{2}$ \\
Loss in fresh water & $0.2-0.5 \mathrm{ecu} / \mathrm{m}^{3}$ \\
\hline
\end{tabular}

Figure 7 shows the total monetised global externalities year 2045. The most important monetised externalities are increased mortality due to the temperature increase, and the loss of fresh water. Other externalities, as the losses in agriculture and forestry, have only marginal contributions.

Coal-fired power plants have the largest monetised value for the global externalities, while those related to wind power can almost be neglected.

It must be stressed that uncertainties related to the evaluation of the global externalities are very high, and that only those types of damage that can be identified today are included. Without doubt, a number of future externalities, not accounted for in the study, will most likely arise. For that reason, the monetised global externalities in this study most probably will account for only a subset of total externalities related to the greenhouse effect.

Using the assumption of a linear relationship between $\mathrm{CO}_{2}$-concentration in the atmosphere and the global damage of the temperature increase, and a discount rate of $1.5 \%$ p.a. (real terms), the average value of the monetised externalities amounts to a little less than half of the values shown in Figure 7. 


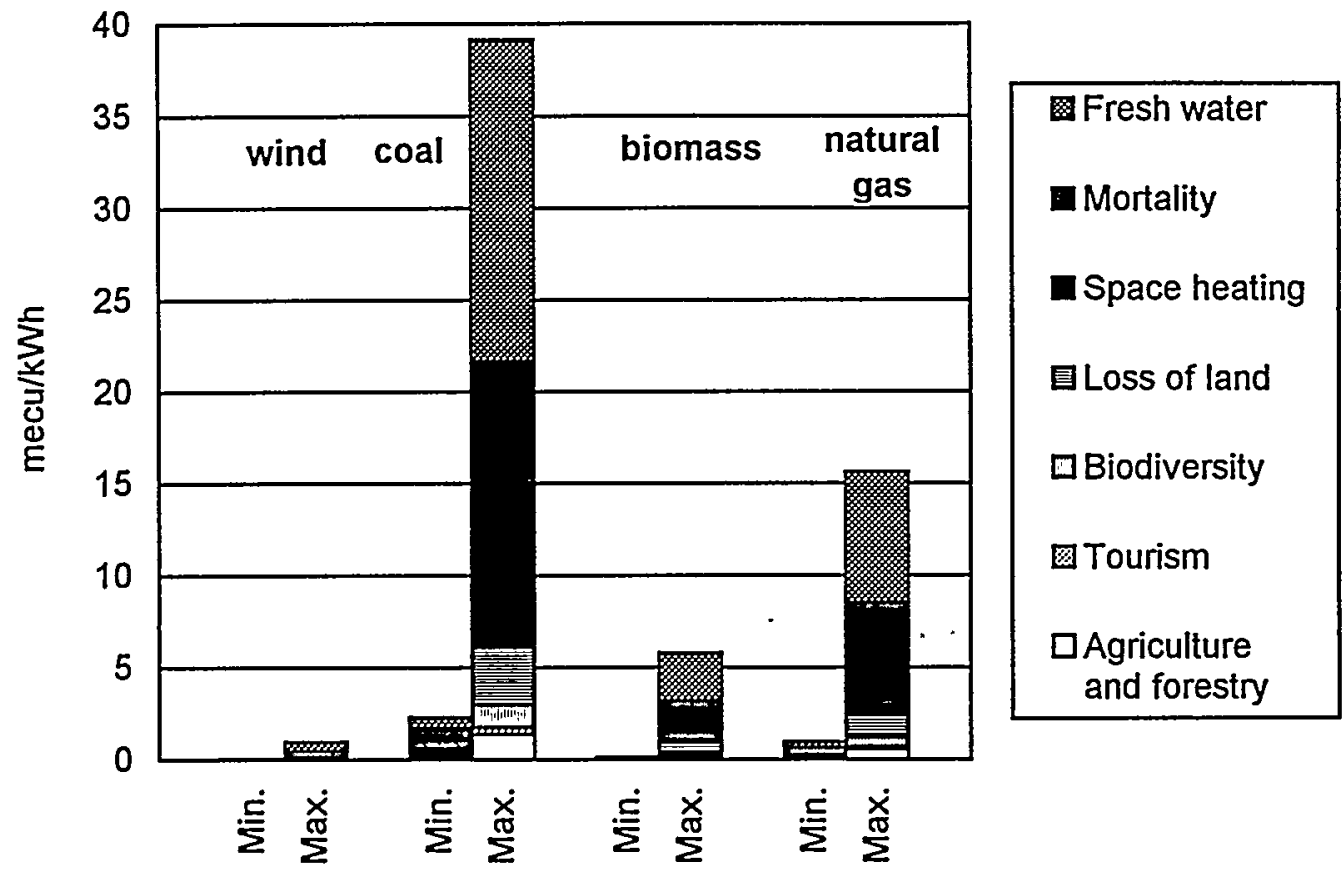

Figure 7. Monetised global externalities, year 2045 


\section{Conclusion}

The Danish project has carried out an analysis of the environmental externalities related to four technologies: Wind power, coal-fired condensing plants, biomass CHP-plants and natural gas CHP plants.

Due to differences in methodology, the analysis was split into two parts: one for local/regional externalities and the other for global externalities.

Concerning the local/regional externalities the following was found:

- The most important monetised values relate to damage to buildings and monuments (acid rain), influences on residences (noise, visual impact) and increased transportation.

- The highest monetised externalities are found in relation to coal-fired power plants and biomass CHP-plants.

In general, the monetised externalities are moderate, mainly due to the use of new, highly efficient technologies in the analysis.

Regarding the global externalities the following was found:

- The most important monetised externalities are increased mortality and loss of fresh water.

- Coal-fired power plants are seen to have the largest monetised externalities, while those for wind power are almost negligible.

- Evaluating global externalities today is highly uncertain. The monetised global externalities can be expected to constitute only a subset of the total existing and future global externalities. 


\section{References}

1. CEC/US, Commission of the European Community, 1993, CEC/US Joint Study on Fuel Cycle Costs. "Assessment of the External Costs of the Coal Fuel Cycle". Draft position paper. Prepared for DG XII of CEC.

2. Cline, W.R., 1992, "The Economics of Global Warming". Washington 1992.

3. Fankhauser, S., 1992/93, "Global Warming Damage Costs: Some Monetary Estimates". CSERGE GEC Working Paper 92-29, revised version, November 1993.

4. Markandya, A., and Rhodes, B., 1992, "External Costs of Fuel Cycles. An Impact Pathway Approach. Economic Valuation". Metroeconometrica Ltd., London.

5. Henrik Meyer et al, 1994, "Omkostningsopgørelse for miljøeksternaliteter $i$ forbindelse med energiproduktion." 
Title and authors

Assessment of environmental external effects in power generation.

Henrik Meyer, Poul Erik Morthorst, Lotte Schleisner

Niels I Meyer, Per Sieverts Nielsen, Vilhjálmur Nielsen

\begin{tabular}{lll}
\hline ISBN & ISSN \\
$87-550-2239-1$ & $0106-2840$ \\
\hline Department or group & Date \\
Systems Analysis Department & December 1996 \\
\hline Groups own reg. number(s) & & Project/contract No. \\
ESG 03350.00 & Tables & $51191 / 92-0067$ \\
\hline Pages & Illustrations & References \\
26 & 7 & 4
\end{tabular}

Abstract (max. 2000 characters)

This report summarises some of the results achieved in a project carried out in Denmark in 1994 concerning externalities. The main objective was to identify, quantify and - if possible - monetise the external effects in the production of energy, especially in relation to renewable energy technologies.

The report compares environmental externalities in the production of energy using renewable and nonrenewable energy sources, respectively. The comparison is demonstrated on two specific case studies. The first case is the production of electricity based on wind power plants compared to the production of electricity based on a coal-fired conventional plant. In the second case heat/power generation by means of a combined heat and power plant based on biomass-generated gas is compared to that of a combined heat and power plant fuelled by natural gas.

In the report the individual externalities from the different ways of producing energy are identified, the stress caused by the effect is assessed, and finally the monetary value of the damage is estimated. The method is applied to the local as well as the regional and global externalities.

Descriptors INIS/EDB

COGENERATION, COMPARATIVE EVALUATIONS, COST BENEFIT ANALYSIS, ECONOMICS, ELECTRIC POWER, ENERGY CONSUMPTION, ENVIRONMENTAL IMPACTS, FOSSIL-FUEL POWER PLANTS, RENEWABLE ENERGY SOURCES 
Risø's objective is to provide society and industry with new opportunities for development in three main areas:

- Energy technology and energy planning

- Environmental aspects of energy, industrial and agricultural production

- Materials and measuring techniques for industry

In addition, Risø advises the authorities on nuclear issues.

\section{Research profile}

Risø's research is strategic, which means that it is long-term and directed towards areas in which technological solutions are called for, whether in Denmark or globally.

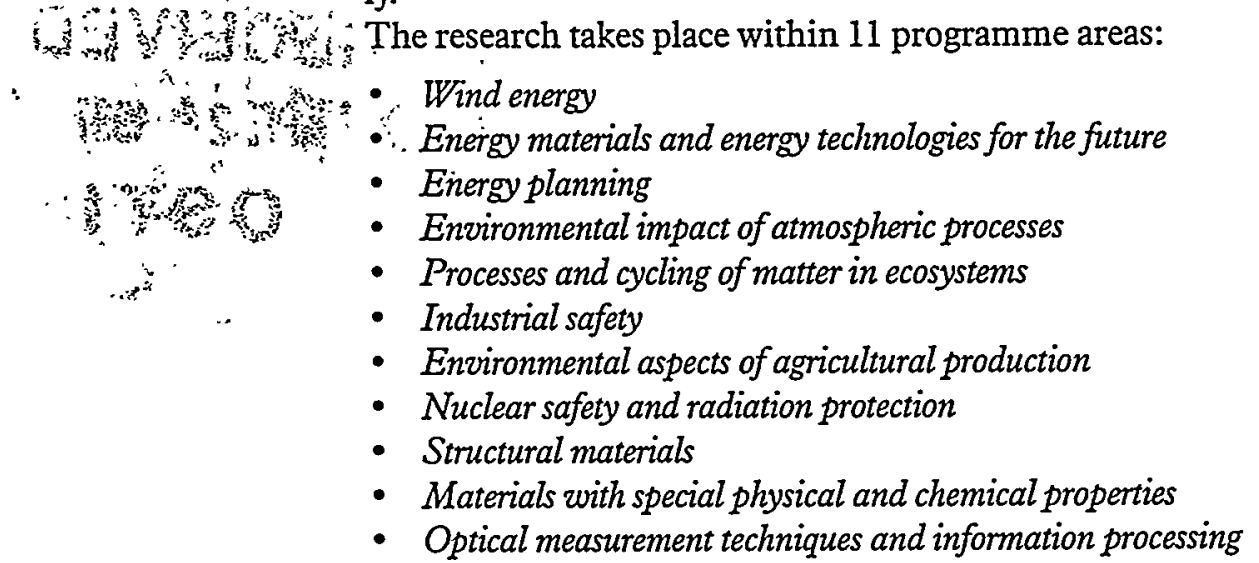

Risø-R-938(EN)

ISBN 87-550-2239-1

ISSN 0106-2840

Available on request from:

Information Service Department

Risø National Laboratory

P.O. Box 49, DK-4000 Roskilde, Denmark

Phone +4546774677 , ext. 4004/4005

Telex 43116, Fax +45 46755627

http://www.risoe.dk

e-mail: risoe@risoe.dk

\section{Transfer of Knowledge}

Risø's research results are transferred to industry and authorities through:

- Co-operation on research

- Co-operation in RED consortia

- $R E D$ clubs and exchange of researchers

- Centre for Advanced Technology

- Patenting and licencing activities

And to the world of science through:

- Publication activities

- Network co-operation

- PhD education and post docs

\section{Key Figures}

Ris $\emptyset$ has a staff of more than 900 , including more than 300 researchers and $100 \mathrm{PhD}$ students and post docs. Risø's 1996 budget totals DKK $471 \mathrm{~m}$, of which $45 \%$ come from research programmes and commercial contracts, while the remainder is covered by government appropriations. 